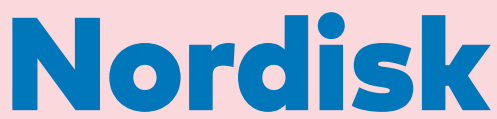

statistik

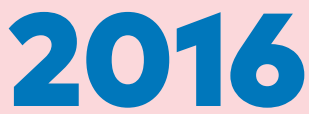

1i) Nordiska

ministerrådet 


\title{
Nordisk statistik 2016
}

Red: Klaus Munch Haagensen, Danmarks Statistik, Ulla Agerskov, Nordiska ministerådet

Databas: Troels A. Vestergaard, Danmarks Statistik

\author{
ANP 2016:759 \\ ISBN 978-92-893-4688-7 (PRINT) \\ ISBN 978-92-893-4689-4 (PDF) \\ http://dx.doi.org/10.6027/ANP2016-759 \\ ISSN 2414-6560 (ONLINE) \\ ISSN 2414-6552 (PRINT)
}

(c) Nordiska ministerrådet 2016

Foto: Scanpix

Tryck: Rosendahls

Upplaga: 2.000

Printed in Denmark

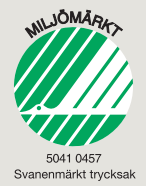

\section{Det nordiska samarbetet}

Det nordiska samarbetet är ett av världens mest omfattande regionala samarbeten. Det omfattar Danmark, Finland, Island, Norge och Sverige samt Färöarna, Grönland och Åland.

Det nordiska samarbetet är politiskt, ekonomiskt och kulturellt förankrat och är en viktig partner i europeiskt och internationellt samarbete. Den nordiska gemenskapen arbetar för ett starkt Norden i ett starkt Europa.

Det nordiska samarbetet ska stärka nordiska och regionala intressen och värderingar i en global omvärld. Gemensamma värderingar länderna emellan bidrar till att stärka Nordens ställning som en av världens mest innovativa och konkurrenskraftiga regioner. 
Nordisk statistik

2016 
Mera statistik på

www.norden.org/fakta 


\section{Förord}

De nordiska länderna är små var för sig, men tillsammans är de betydelsefulla. Visste du till exempel att om man slår samman ländernas bruttonationalprodukter blir Norden världens tolfte största ekonomi? Eller att regionen Norden är större än hela Indien och därmed den sjunde största i världen?

Den här fickversionen av Nordisk statistik 2016 ger dig en liten inblick i statistiken som tecknar konturerna av våra nordiska samhällen - till exempel att invånarna på Island i snitt går på teater dubbelt så ofta som man gör i Norge, Danmark och Sverige.

Om du vill fördjupa dig ytterligare i nordisk statistik kan du besöka www.norden.org/fakta. Där hittar du databasen Nordisk statistikbank och fler siffror som öppnar för många intressanta analyser.

Trevlig läsning! 
Symboler

Noll

Mindre än hälften $\quad 0$

Inte tillämpligt

Uppgift saknas

Länk till databas

Landskoder

Danmark DK

Färöarna FO

Grönland GL

Finland $\quad \mathrm{FI}$

Åland AX

Island IS

Norge NO

Sverige SE

Norden NR

Euroområdet EA

Europeiska unionen EU 


\section{Innehåll / teman}

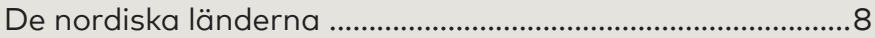

Norden i ett internationellt sammanhang ............................10

Klimat och energi ...................................................................... 16

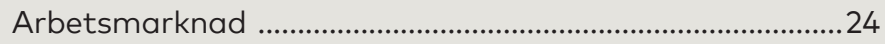

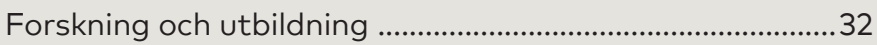

Innovation och kreativitet ........................................................ 40

Sociala tjänster och jämlikhet ..................................................46

Förtroende och öppenhet..........................................................52

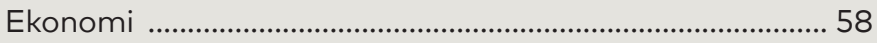




\section{De nordiska länderna}

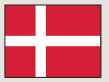

Danmark

Areal km²

43561

Befolkning

Statskick/Status

5707251

Statsöverhuvud

Konstitutionell monarki

Huvudstad

Drottning Margrethe II

1280371 (Köpenhamn)

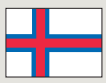

Färöarna

Areal km²

Befolkning

Statsskick/Status

Statsöverhuvud

Huvudstad

1396

48704

Självstyre, del av Kungariket Danmark

Drottning Margrethe II

20521 (Torshamn)

\section{Grönland}

Areal km²

Befolkning

2166086

Statsskick/Status 55847

Statsöverhuvud

Huvudstad

Självstyre, del av Kungariket Danmark

Drottning Margrethe II

17316 (Nuuk)

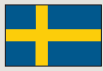

\section{Sverige}

Areal km²

Befolkning

447435

9851017

Statsskick/Status

Konstitutionell monarki

Statsöverhuvud

Kung Carl XVI Gustav

Huvudstad

2231439 (Stockholm) 

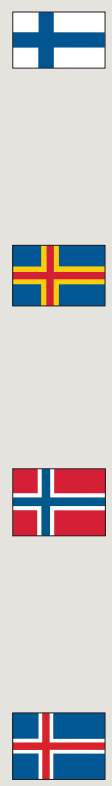

\section{Island}

Areal km2

Befolkning Statsskick/Status Statsöverhuvud Huvudstad
338430

5487308

Republik

President Sauli Niinistö

1122101 (Helsingfors)

1581

28916

Självstyre, del av republiken Finland President Sauli Niinistö 11461 (Mariehamn)

323781

5213985

Konstitutionell monarki

Kung Harald $V$

1252923 (Oslo)
103492

332529

Republik

President Guðni Jóhannesson 213619 (Reykjavik) 


\section{NYCKELTAL 2015*}

\section{Norden i ett internationellt sammanhang}

*2015 eller senast tillgängliga siffror. Norden består i denna tabell av Danmark, Finland, Island, Norge och Sverige. EU: De 27 eller 28 medlemsstaterna i Europeiska unionen per 1 januari 2013 eller 1 januari 2014. PPS: Purchasing power standards - köpkraftspariteter som eliminerar skillnader i prisnivå mellan länderna. 
Total landareal

$1000 \mathrm{~km}^{2}$

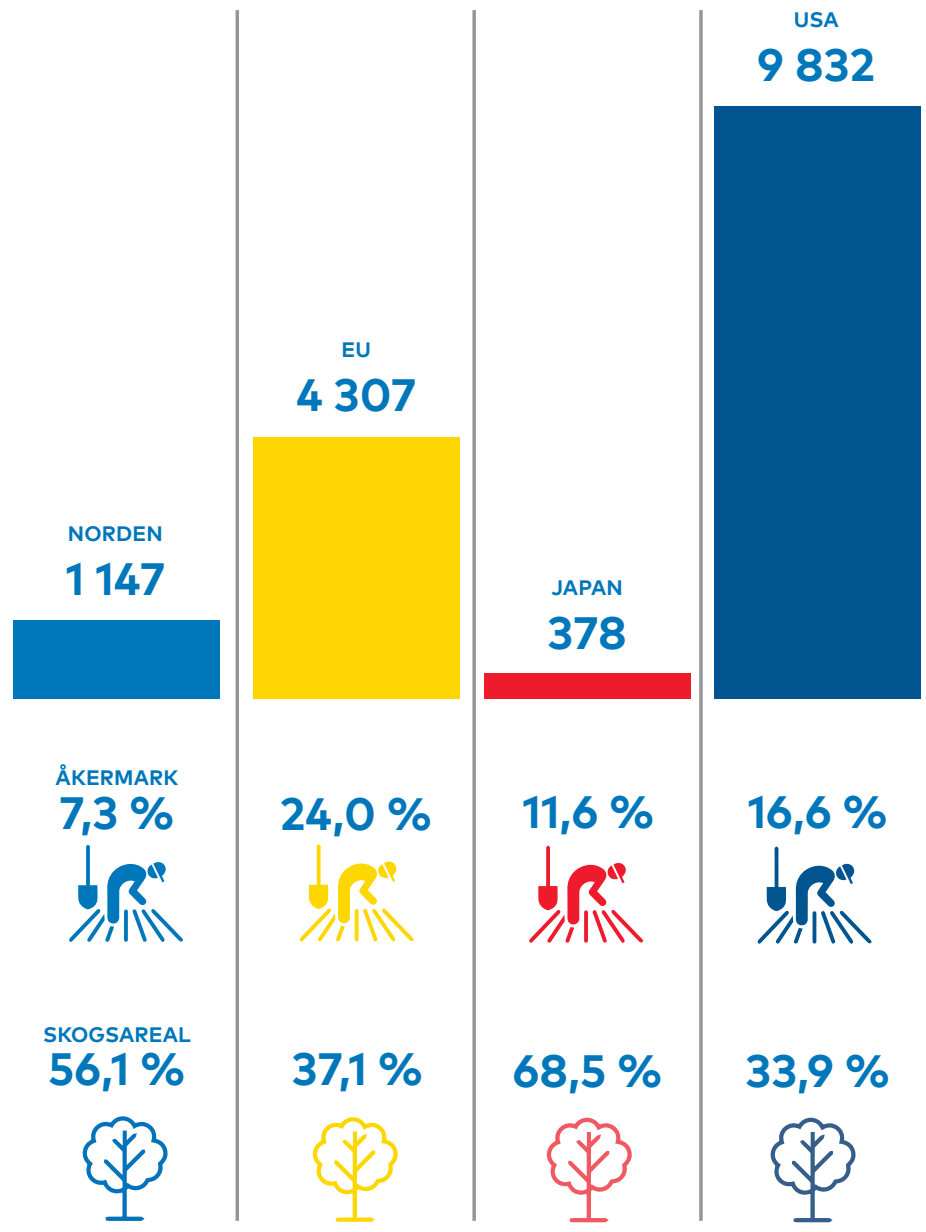




\title{
Folkmängd
}

\author{
(miljoner)
}

NORDEN

EU

JAPAN

USA
27 mi

509

127 กัง

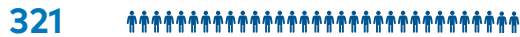

\section{Befolkningstäthet}

(invånare $/ \mathrm{km}^{2}$ )

NORDEN

17

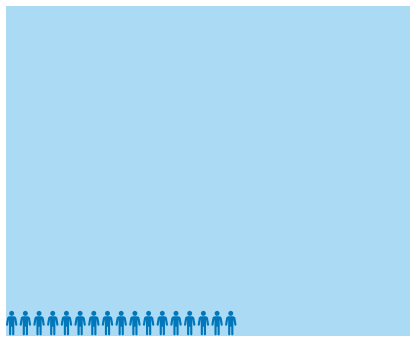

JAPAN

336

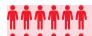

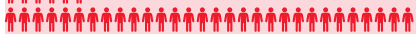

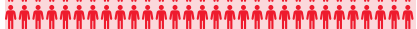

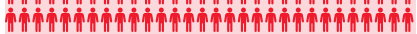

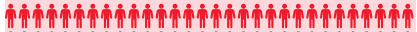

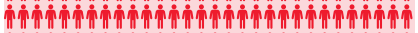

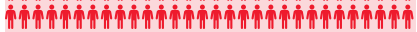

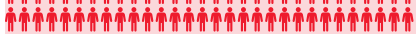

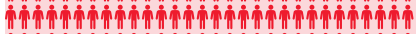

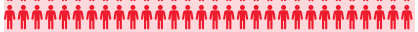

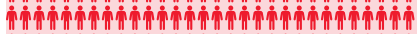

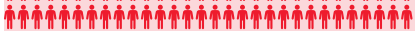

EU

118

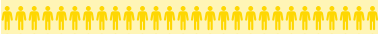

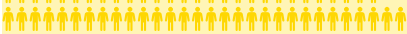

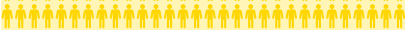

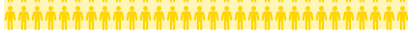

USA

33

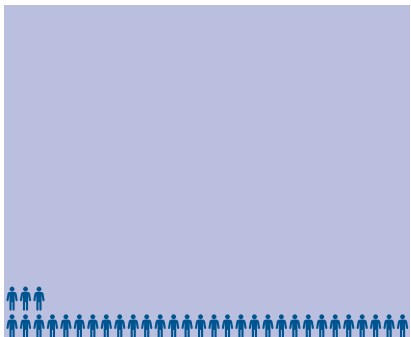


Summerade

fruktsamhetstal

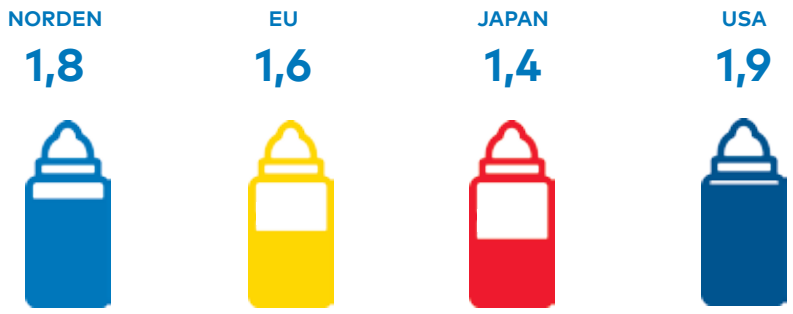

Medellivslängd

(år)

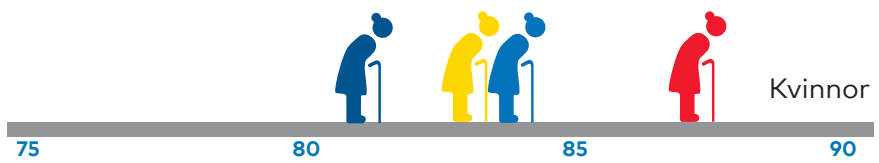

- USA 81,4 EU 83,6 NORDEN 83,8 - JAPAN 86,8

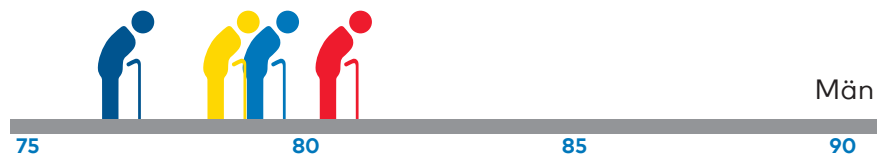

- USA 76,6 EU 78,1 - NORDEN 79,7 - JAPAN 80,5 


\section{BNP}

(miljarder USD)

NORDEN

1277

EU

19191

JAPAN

4738

USA

17947

\section{BNP per person}

(PPS, USD)

$\begin{array}{ll}\text { NORDEN } & 48335 \\ \text { EU } & 37691 \\ \text { JAPAN } & 36581 \\ \text { USA } & 54353\end{array}$

BNP tillväxt

(procent)

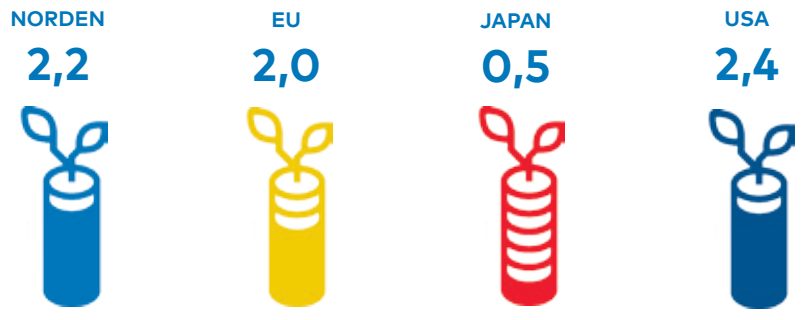




\section{Total skattesats}

(procent av BNP)

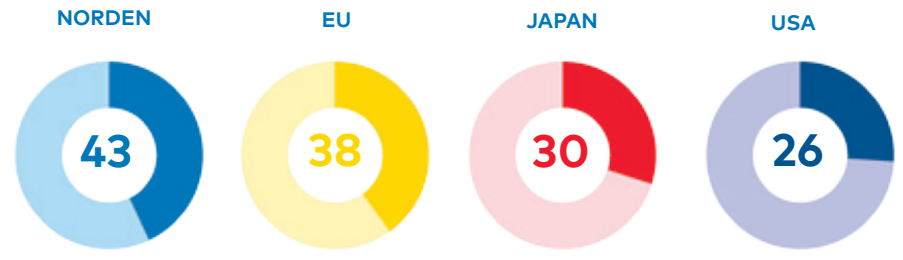

\section{Export / import}

(miljarder USD)

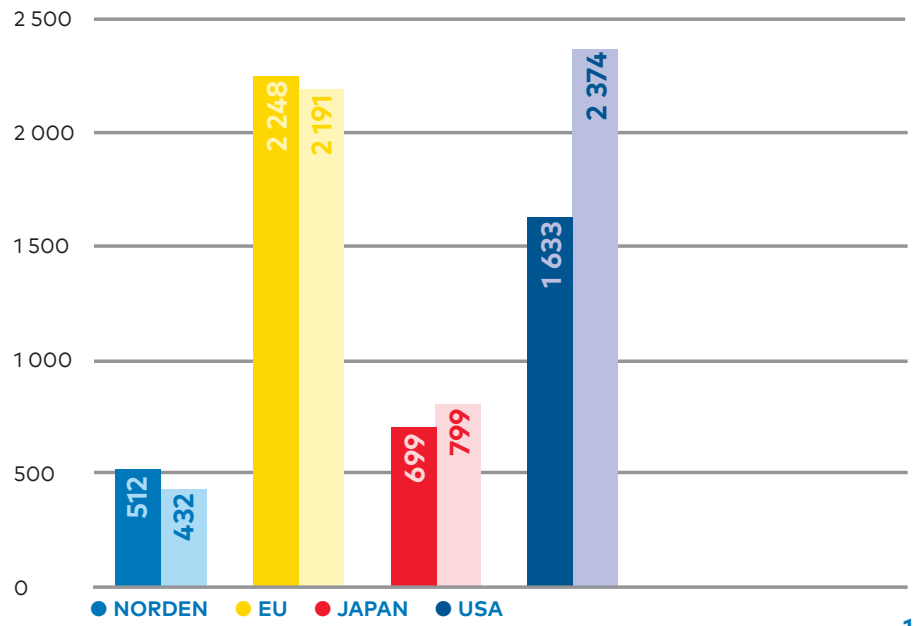


Klimat och energi 
Medeltemperatur i de nordiska huvudstäderna

10 Grader Celsius

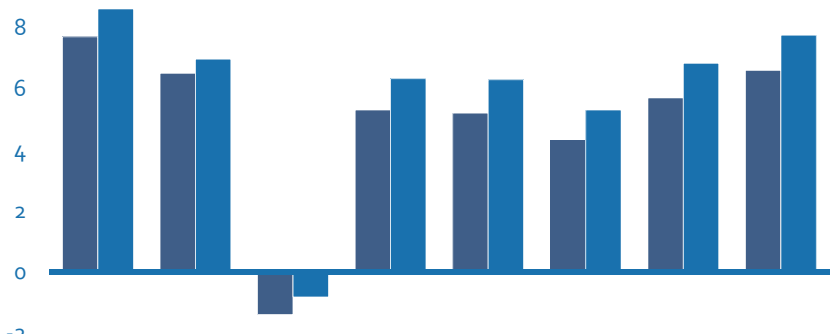

$-2$
DK
FO
GL
FI
AX
IS NO
SE
- Medeltemperatur 1961-1990 - Medeltemperatur 1990-2015

묘 Tempo1. Danmark, Grönland och Åland: 1990-2014 års uppgifter. Island: 1997-2015 års uppgifter.

\section{Utsläpp av växthusgaser, per person}

$16 \mathrm{CO}_{2}$-ekvivalenter, ton

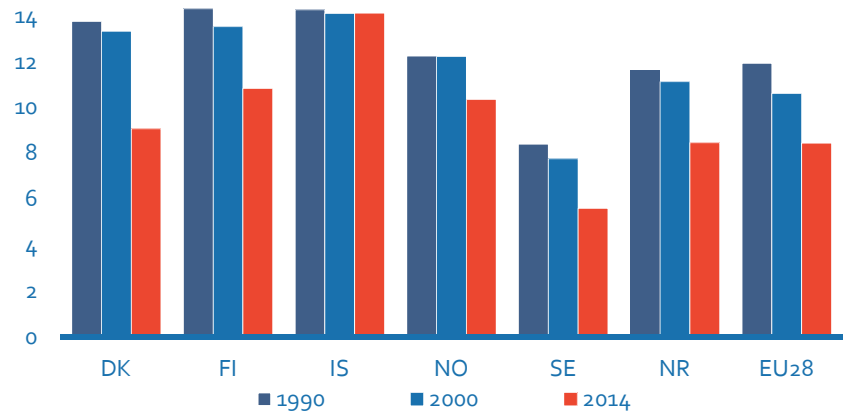

马 Indic302 och Popuo2 
Inhemsk energiproduktion 2014

Norden

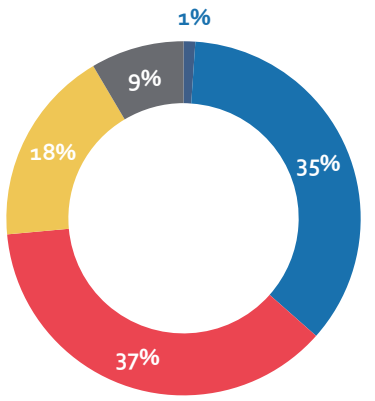

- Kol

- Olja

- Gas

⿴囗十 Förnyelsebara bränslen

- Kärnkraft

몰

$\mathrm{EU}_{28}$

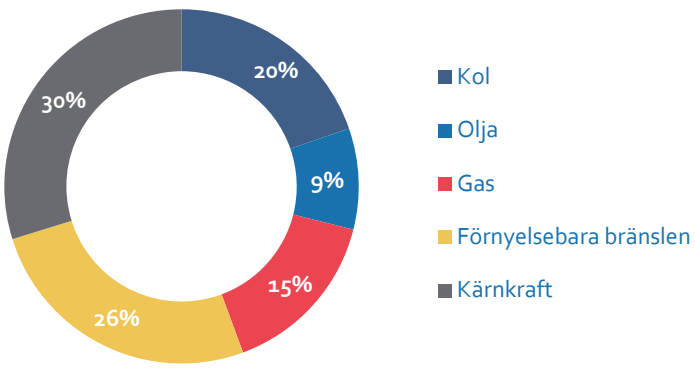

톨 
Den totala inhemska energiförbrukningen 2014

Norden

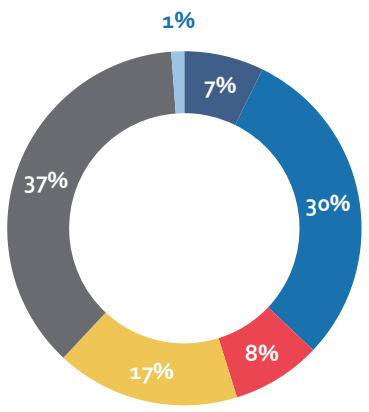

- Kol

- Olja

Gas

Kärnkraft

- Förnyelsebara bränslen

m Övrigt

Enero5

$\mathrm{EU}_{28}$

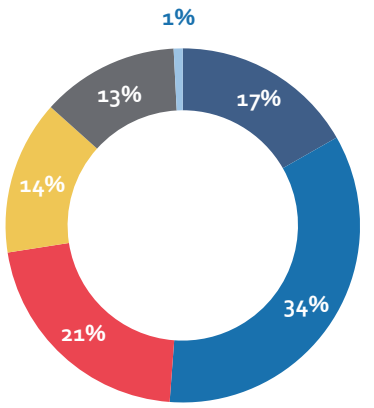

- Kol

- Olja

- Gas

- Kärnkraft

— Förnyelsebara bränslen

n Övrigt

$\square$ Enero5 
Slutlig inhemsk energianvändning 2014

Norden

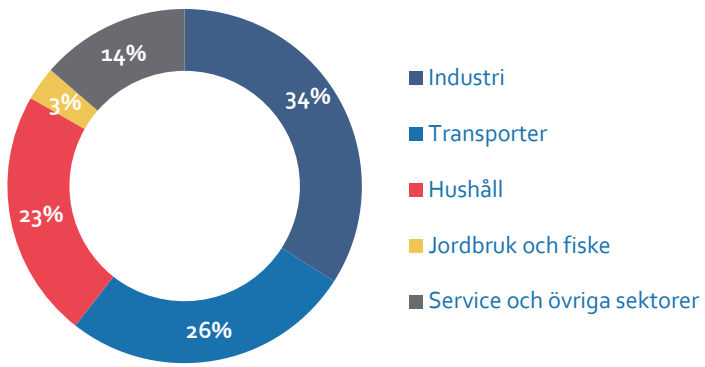

므료 Eno

$\mathrm{EU}_{28}$

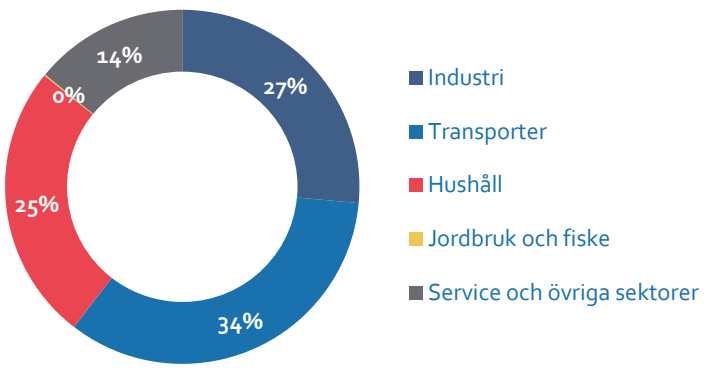

Ener10 
Avlänkning mellan miljöbelastning och ekonomisk tillväxt
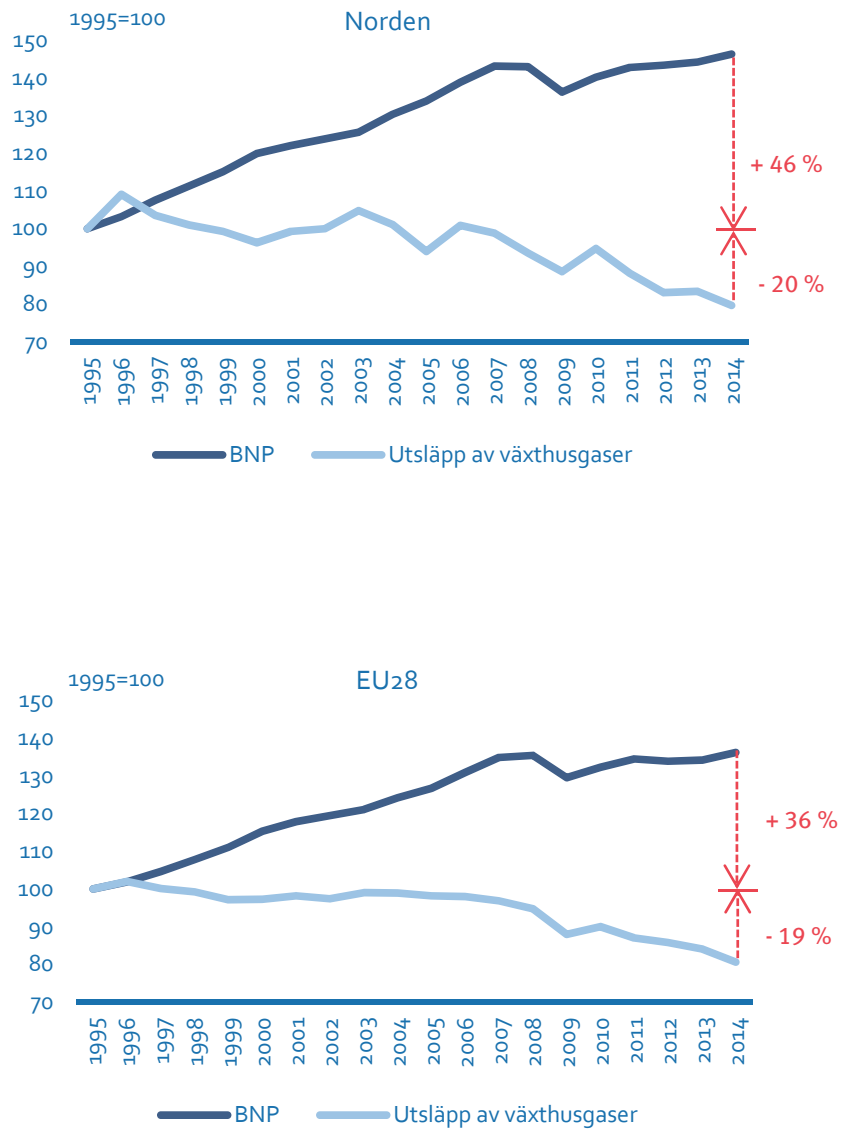

曰Indic401 


\section{Miljöskatter}

8 Procent av totala skatter

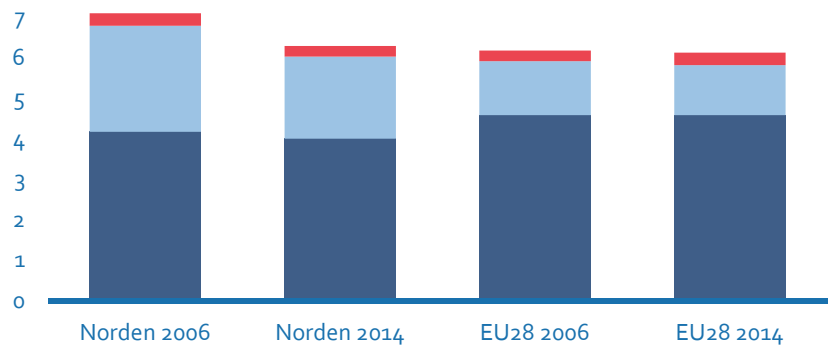

Energiskatter - Transportskatter $\quad$ Skatter på föroreningar och resurser 且Pubs15

\section{Ekologiskt jordbruk}

25 Andel av det totala jordbruksområdet

20

15

10

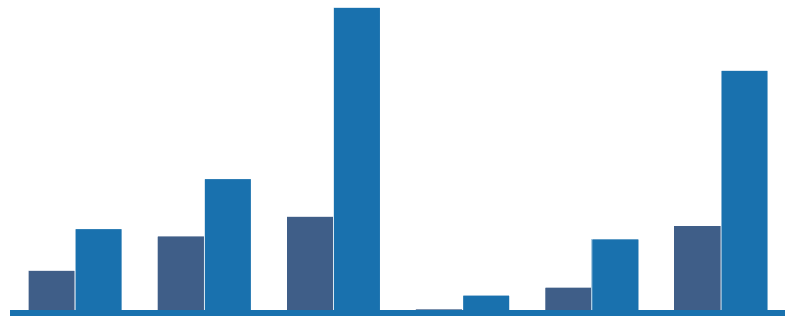

DK

$\mathrm{FI}$

AX

IS

NO

SE

- 2000

2014

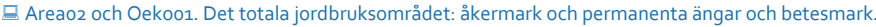
Sverige: $2000=2002$ års uppgifter. Åland: Endast åkermark. 


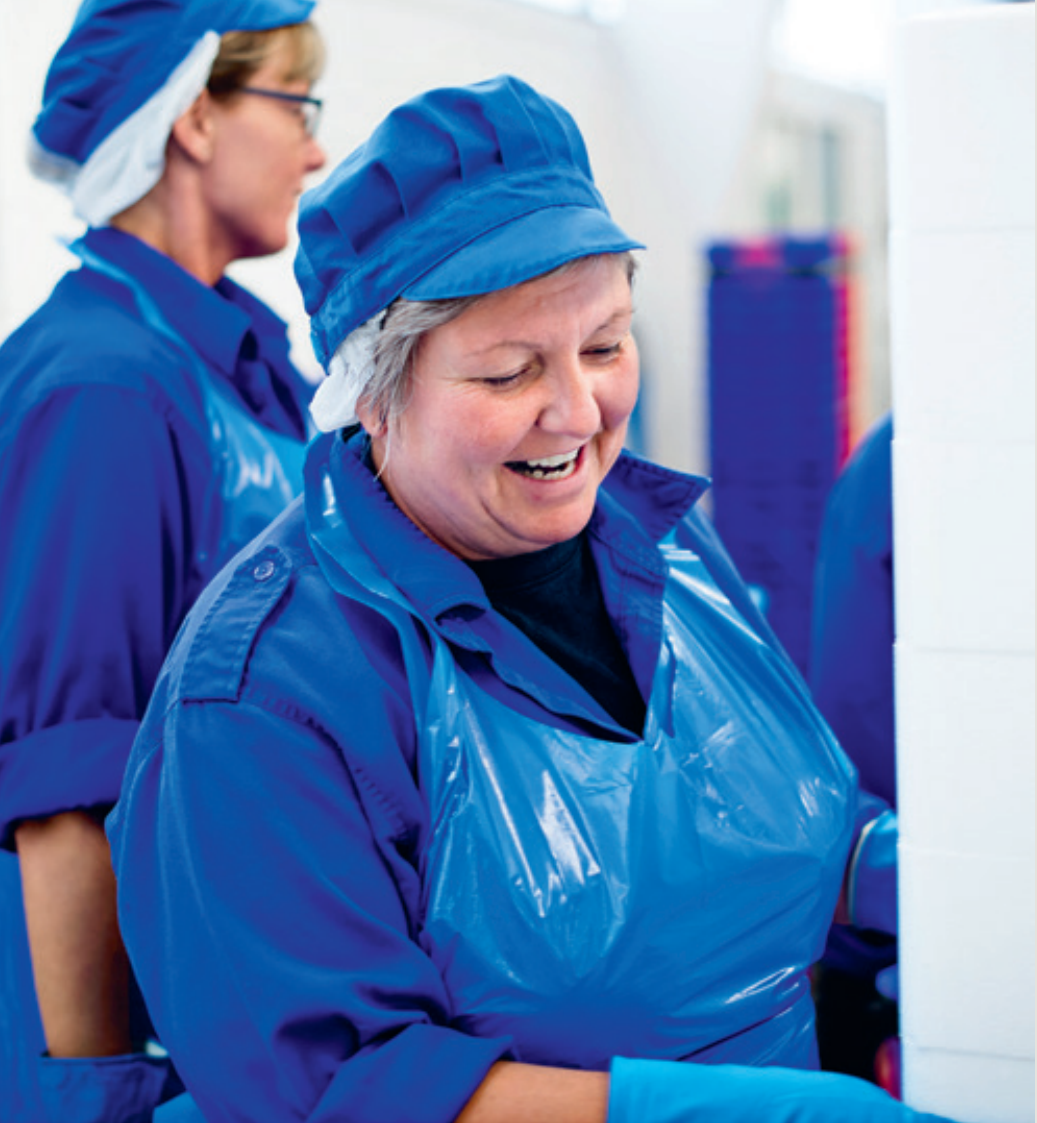

Två tredjedelar av alla kvinnor

i Norden jobbar heltid. 
Arbetsmarknad 
Sysselsättningsgrad 2015

100 Procent av åldersgruppen 15-64 år

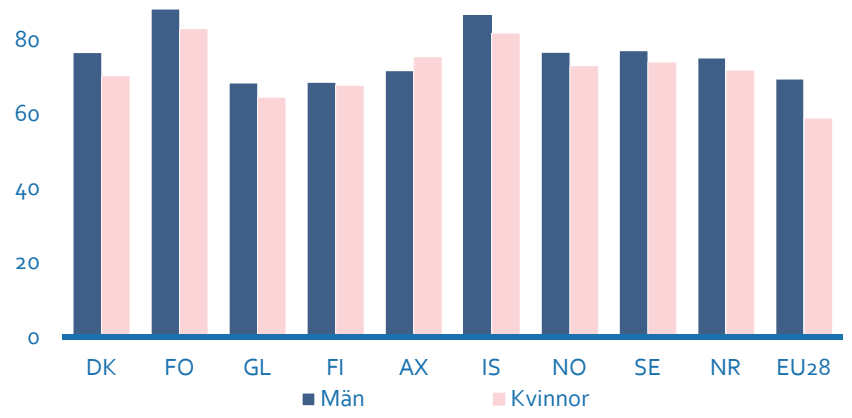

므 Work02. Åland: 2011 års uppgifter. Grönland, Färöarna och EU28: 2014 års uppgifter.

\section{Alla sysselsatta efter kön 2015}

Norden

$\mathrm{EU}_{28}$

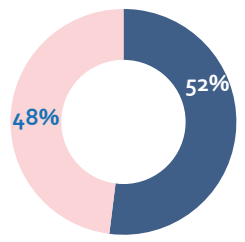

- Män

Kvinnor

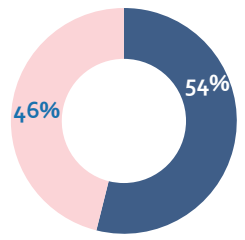


Arbetslöshet

12 Procent av åldersgruppen $15-64$ år

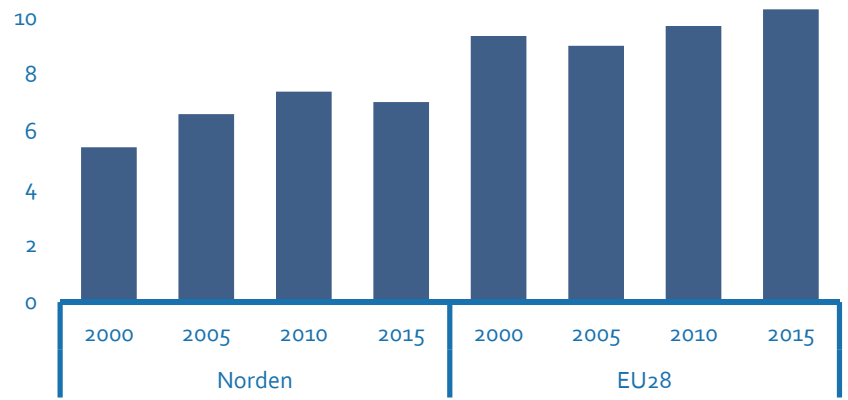

Worko2

\section{Ungdomsarbetslöshet 2015}

25 Procent av åldersgruppen 15-24 år

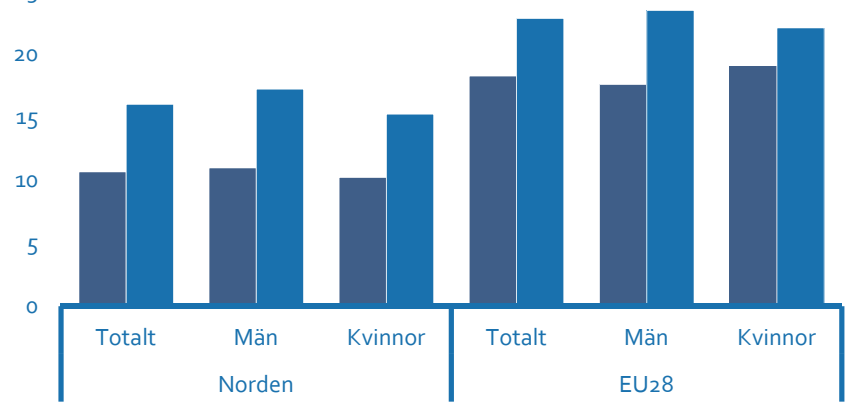

घ 2000 - 2015

믄. Work2 
Arbetsfrånvaro minst en vecka på grund av sjukdom

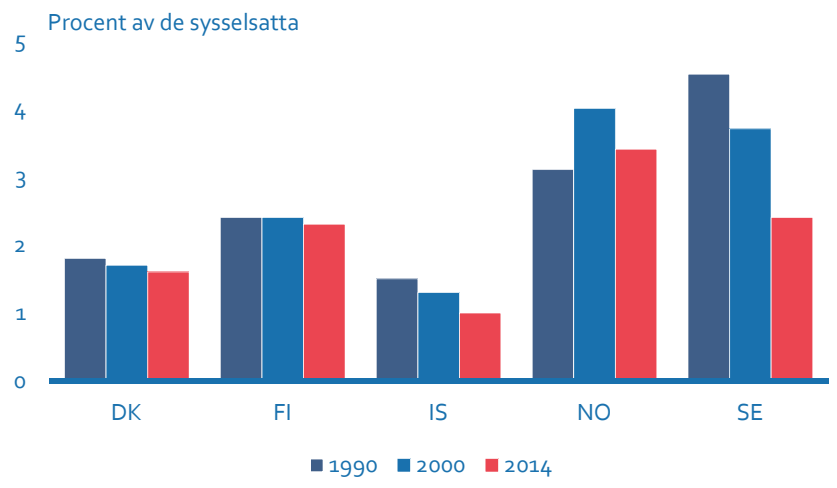

오을

Arbetsfrånvaro minst en vecka på grund av sjukdom 2014

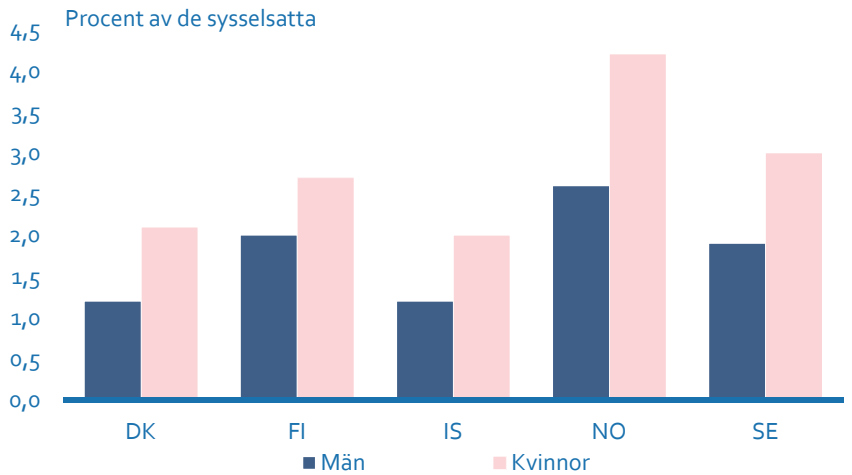

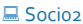


Graviditets- och föräldraledighet

7 Antalet ersättningsdagar uttagna per capita

6

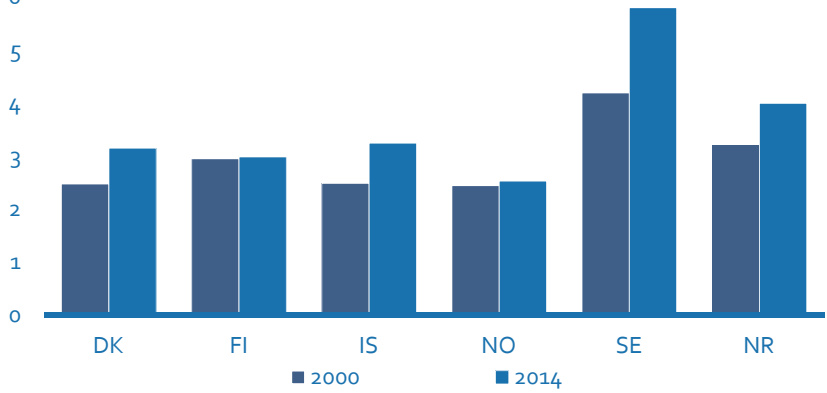

모 Socio 4

35 Andel dagar uttagna av män, procent

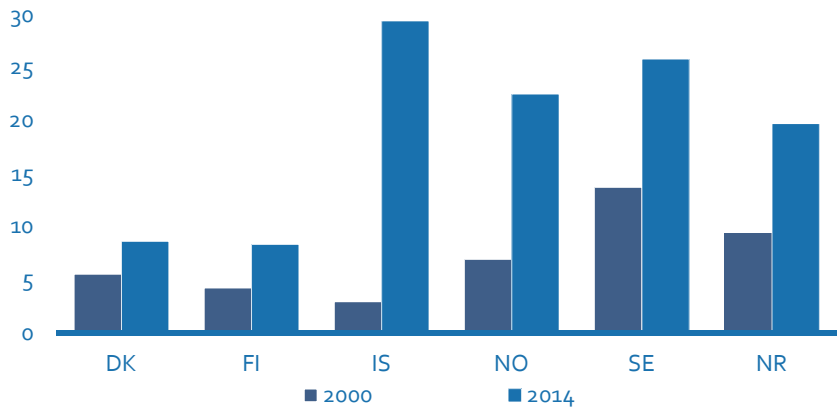

ㅇocio4 


\section{Årlig medianinkomst 2015}

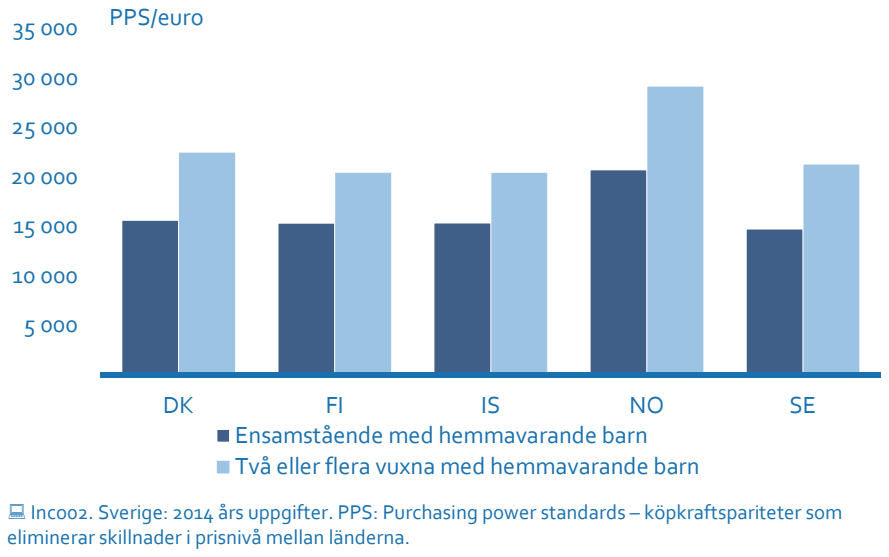


ARBETSMARKNAD 31 


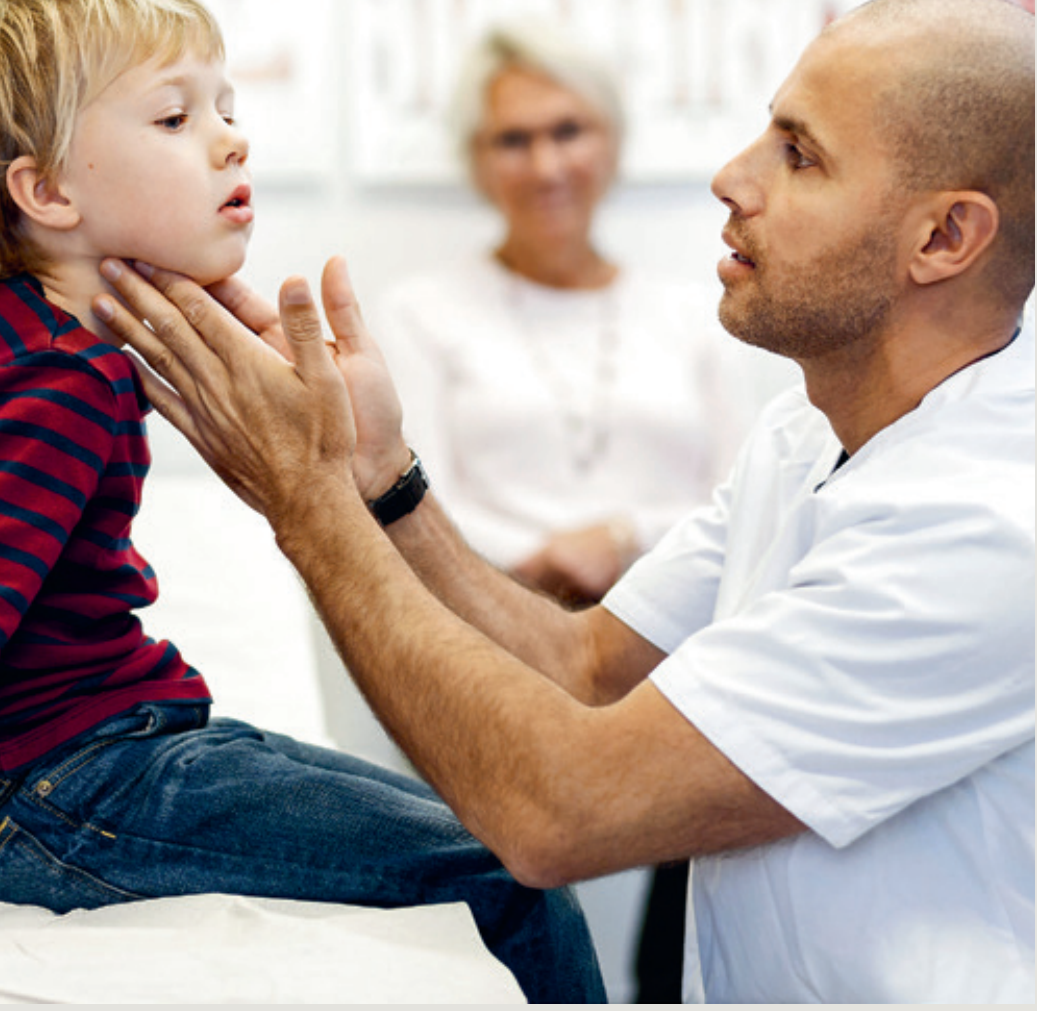

Idag finns mer än tre gånger så många läkare per invånare i Norden än vad det gjorde på 60-talet. 


\section{Forskning \\ och utbildning}


Utbildningsnivå (i åldern 25-74 år) 2015

Norden

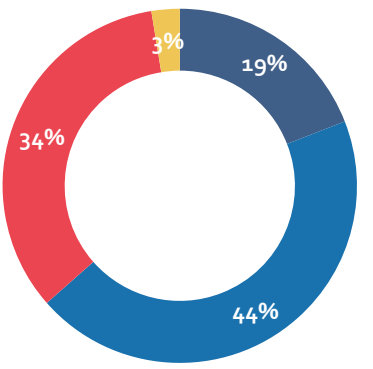

- Grundskola

- Gymnasium och yrkesutbildning

- Universitet och högskola

m Ospecificerat eller okänt

Educo1

$\mathrm{EU}_{28}$

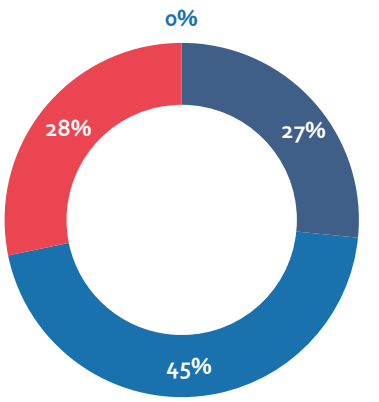

- Grundskola

- Gymnasium och yrkesutbildning

- Universitet och högskola

- Ospecificerat eller okänt 
Elevers prestationer, PISA 2012

\begin{tabular}{|c|c|c|c|c|c|}
\hline \multicolumn{2}{|l|}{ Läsförståelse } & \multicolumn{2}{|c|}{ Kunskaper i matematik } & \multicolumn{2}{|c|}{ Kunskaper i naturvetenskap } \\
\hline Japan & 538 & Sydkorea & 554 & Japan & 547 \\
\hline Sydkorea & 536 & Japan & 536 & Finland & 545 \\
\hline Finland & 524 & Schweiz & 531 & Estland & 541 \\
\hline Kanada & 523 & Nederländerna & 523 & Sydkorea & 538 \\
\hline Irland & 523 & Estland & 521 & Polen & 526 \\
\hline Polen & 518 & Finland & 519 & Kanada & 525 \\
\hline Estland & 516 & Kanada & 518 & Tyskland & 524 \\
\hline Nya Zeeland & 512 & Polen & 518 & Nederländerna & 522 \\
\hline Australien & 512 & Belgien & 515 & Irland & 522 \\
\hline Nederländerna & 511 & Tyskland & 514 & Australien & 521 \\
\hline Belgien & 509 & Österrike & 506 & Nya Zeeland & 516 \\
\hline Schweiz & 509 & Australien & 504 & Schweiz & 515 \\
\hline Tyskland & 508 & Slovenien & 501 & Storbritannien & 514 \\
\hline Frankrike & 505 & Irland & 501 & Slovenien & 514 \\
\hline Norge & 504 & Nya Zeeland & 500 & Tjeckien & 508 \\
\hline Storbritannien & 499 & Danmark & 500 & Österrike & 506 \\
\hline USA & 498 & Tjeckien & 499 & Belgien & 505 \\
\hline Danmark & 496 & Frankrike & 495 & OECD & 501 \\
\hline OECD & 496 & OECD & 494 & Frankrike & 499 \\
\hline Tjeckien & 493 & Storbritannien & 494 & Danmark & 498 \\
\hline Italien & 490 & Island & 493 & USA & 497 \\
\hline Österrike & 490 & Luxemburg & 490 & Spanien & 496 \\
\hline Ungern & 488 & Norge & 489 & Norge & 495 \\
\hline Portugal & 488 & Portugal & 487 & Ungern & 494 \\
\hline Spanien & 488 & Italien & 485 & Italien & 494 \\
\hline Luxemburg & 488 & Spanien & 484 & Luxemburg & 491 \\
\hline Israel & 486 & Slovakien & 482 & Portugal & 489 \\
\hline Island & 483 & USA & 481 & Sverige & 485 \\
\hline Sverige & 483 & Sverige & 478 & Island & 478 \\
\hline Slovenien & 481 & Ungern & 477 & Slovakien & 471 \\
\hline Grekland & 477 & Israel & 466 & Israel & 470 \\
\hline Turkiet & 475 & Grekland & 453 & Grekland & 467 \\
\hline Slovakien & 463 & Turkiet & 448 & Turkiet & 463 \\
\hline Chile & 441 & Chile & 423 & Chile & 445 \\
\hline Mexiko & 424 & Mexiko & 413 & Mexiko & 415 \\
\hline
\end{tabular}

Pisao1 
Inskrivna studerande på universitet och högskola

Procent av åldersgruppen 20-39 år

25

20

15

10

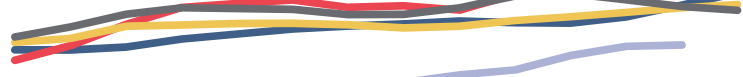

5

0

20002001200220032004200520062007200820092010201120122013

$\longrightarrow \mathrm{DK}=\mathrm{GL} \longrightarrow \mathrm{FI} \longrightarrow \mathrm{AX} \longrightarrow \mathrm{IS}=\mathrm{NO}$

Educo2 och Popuo2

16 Procent av åldersgruppen 20-39 år, Norden totalt

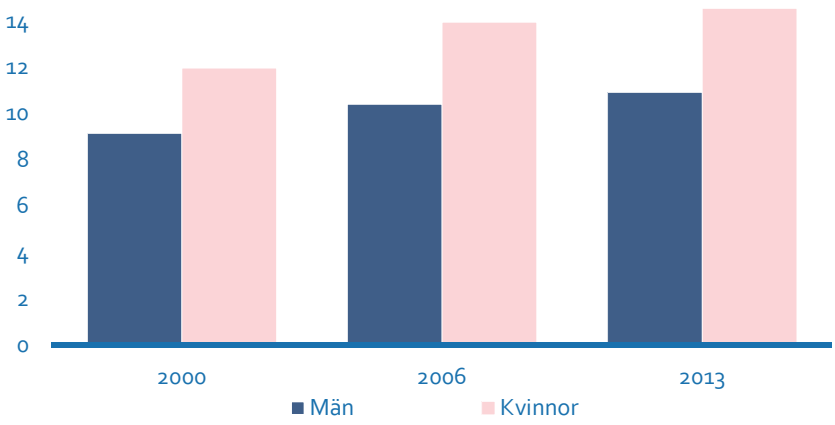

Educo2 och Popuo2 
Studiestöd 2015

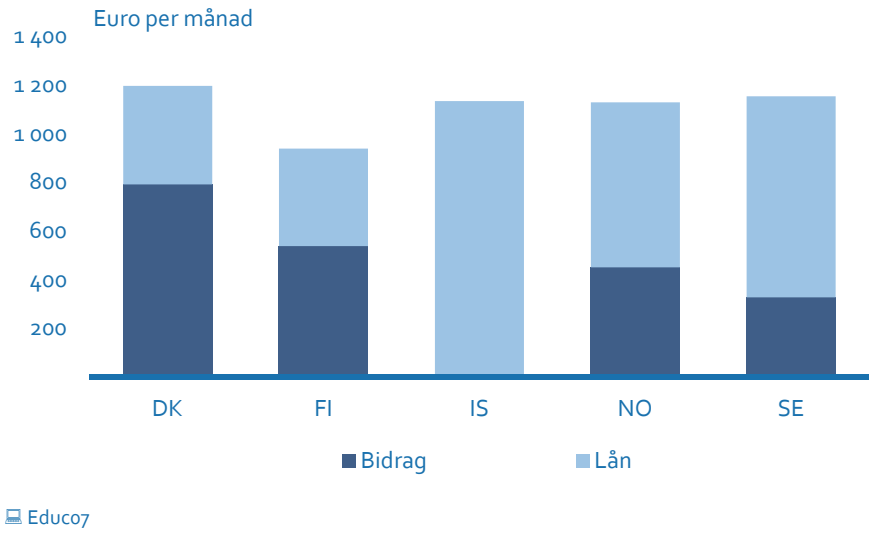

Filosofie doktorer 2014

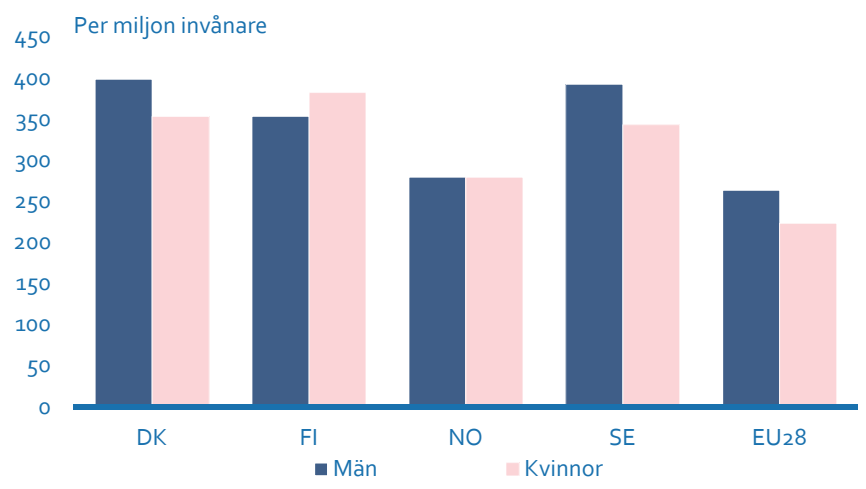

马 Phdgo2. EU28: 2013 års uppgifter. 
FoU-personal

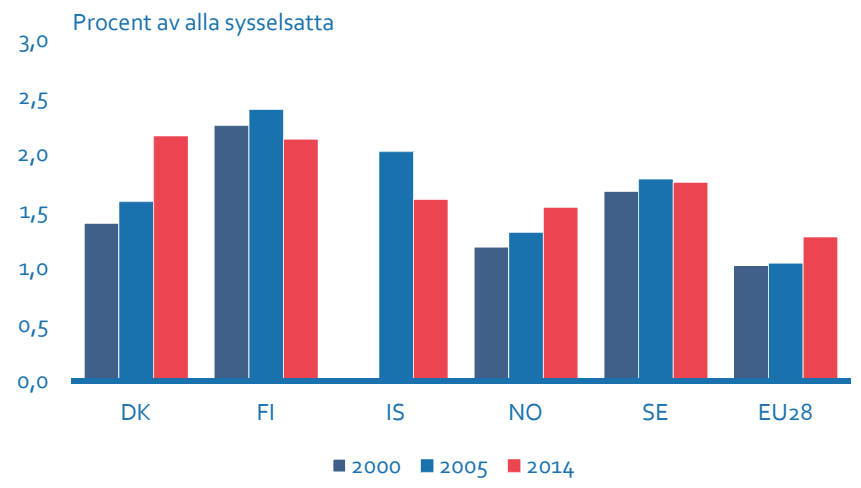

몰eo4

Totala statliga FoU-utgifter

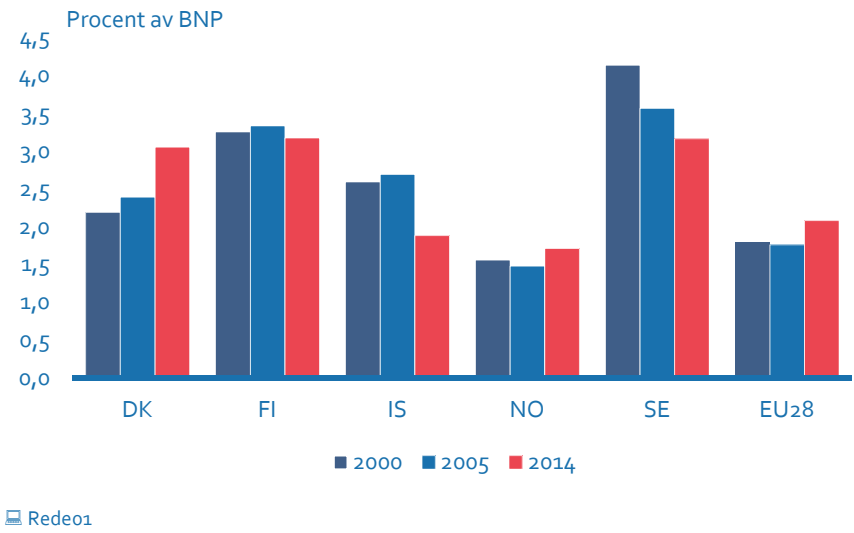


Nybildade företag

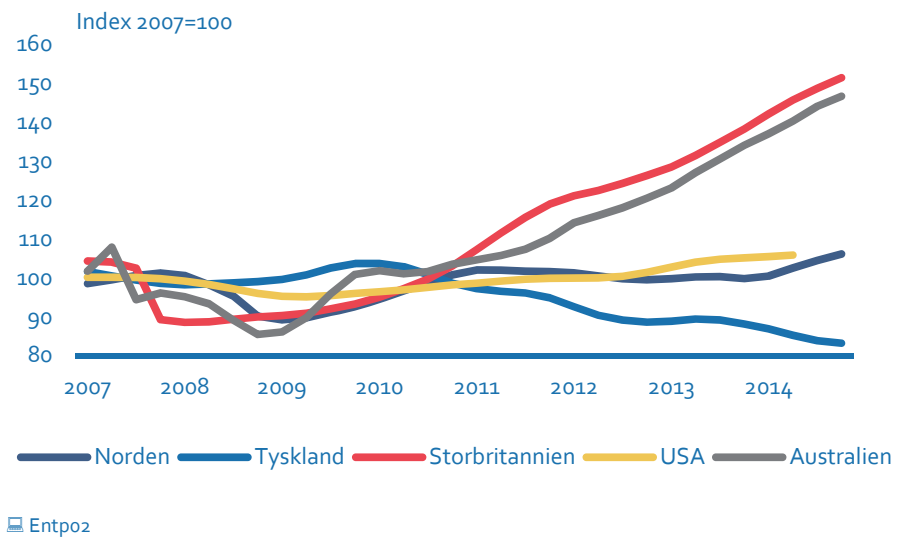





\section{Innovation och kreativitet}




\section{Patent 2015}

600 Per miljon invånare

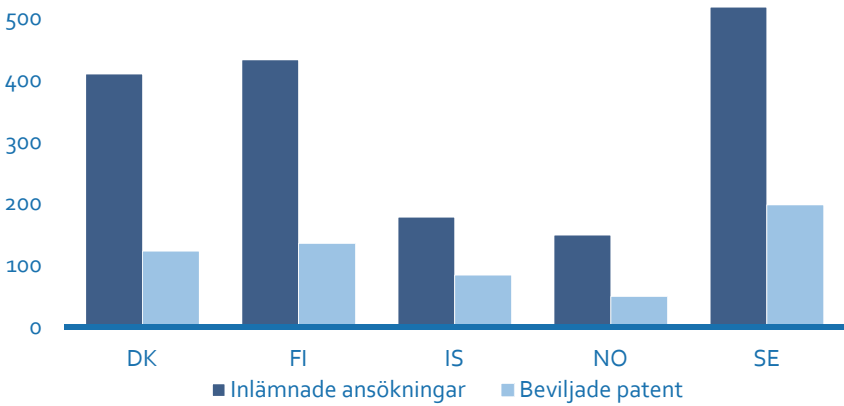

Pateo1

Anställda inom kultursektorn

Procent av den totala sysselsättningen

5,0

4,5

4,0

3,5

3,0

2,5

2,0
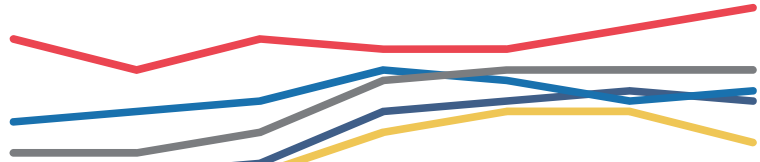

2008

2009

2010

2011

2012

2013

2014

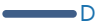

DK

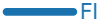

IS

$\longrightarrow$ NO

$\longrightarrow$ SE

$\mathrm{EU}_{28}$

Cult23 
Offentliga utgifter till kultur och fritidsverksamhet 2014

Euro per invånare

1400

1200

1000

800

600

400

200

0

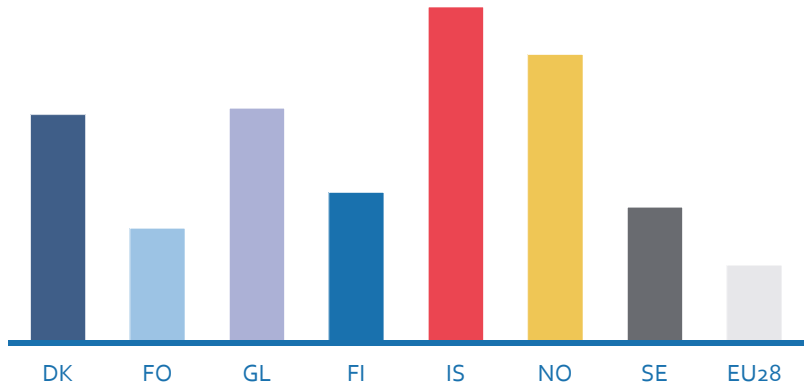

므 Cult20. Färöarna: 2009 års uppgifter. Grönland: 2012 års uppgifter.

Offentliga utgifter till kultur och fritidsverksamhet

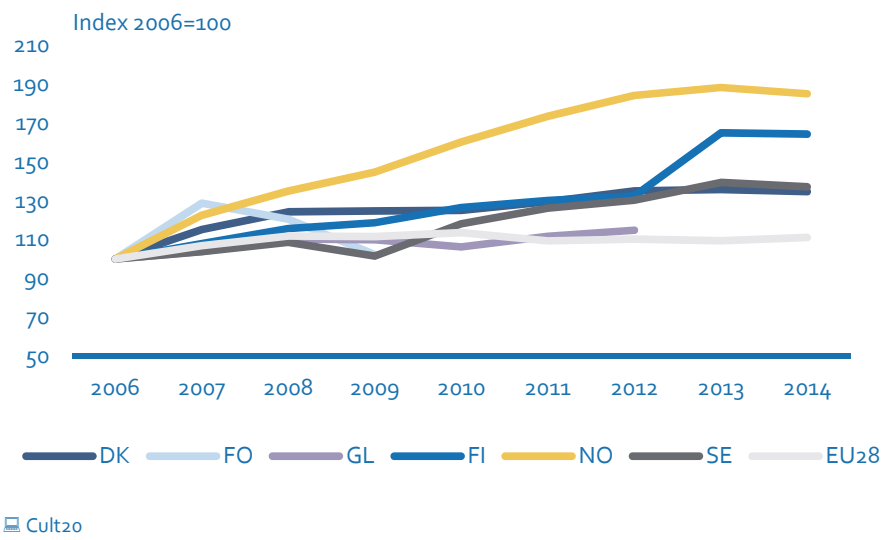


Filmpremiärer 2015

Andel av nordiska filmpremiärer

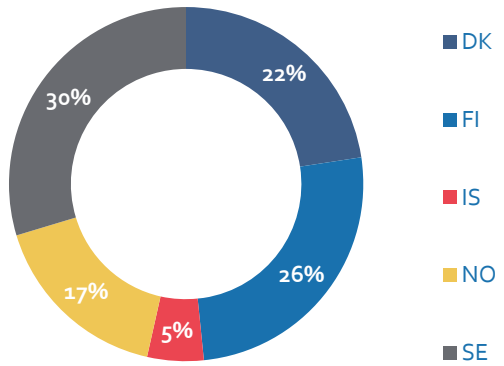

口 Culto5

Filmpremiärer 2015

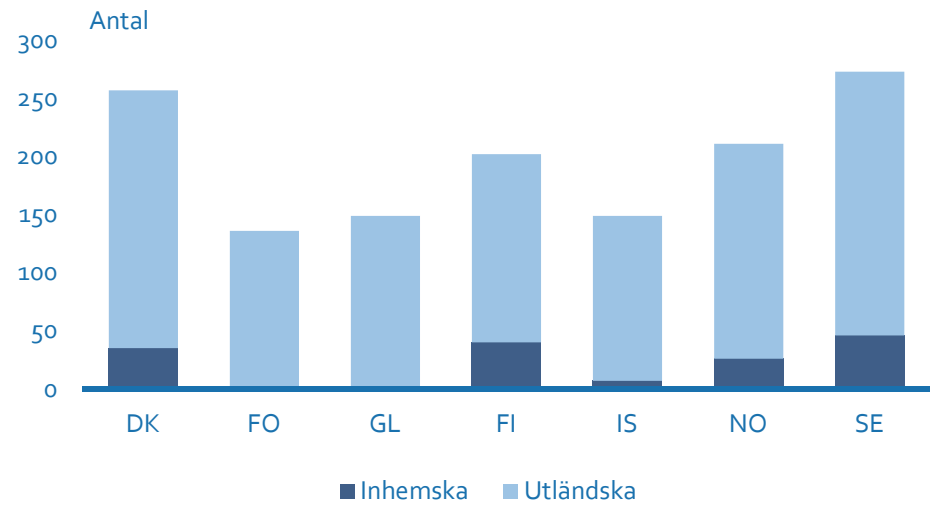

ulto5 


\section{Teaterbesök 2015}

Antal besök per 100 invånare

90

80

70

60

50

40

30

20

10

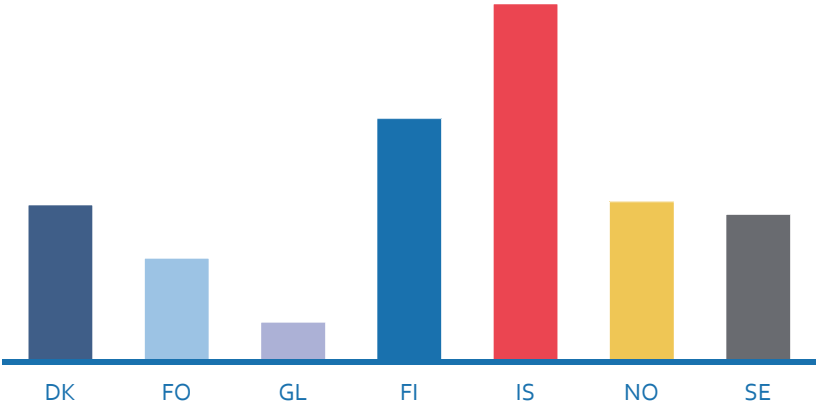

묘 Cult15. Island och Grönland: 2014 års uppgifter. Sverige: 2010 års uppgifter. 


\section{Sociala tjänster och jämlikhet}




\section{Ginikoefficient}

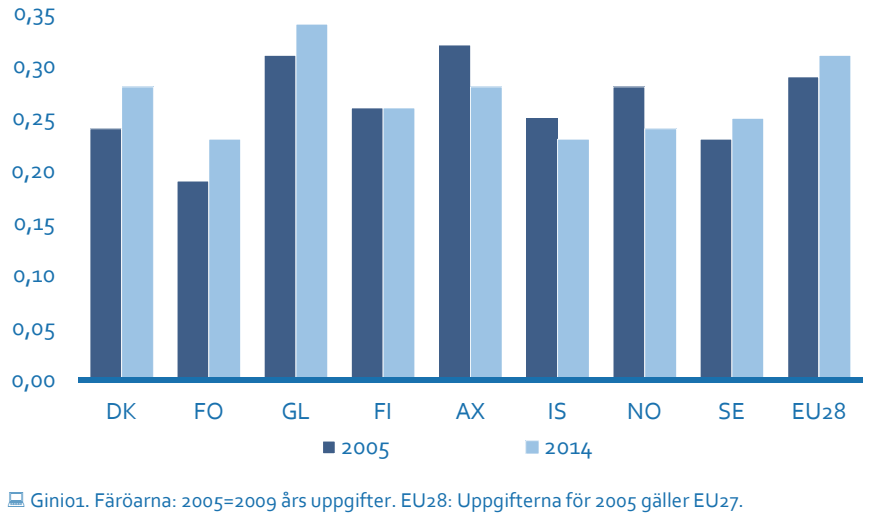

Risk för fattigdom 2014

25 Procent av hushållen

20

15

10

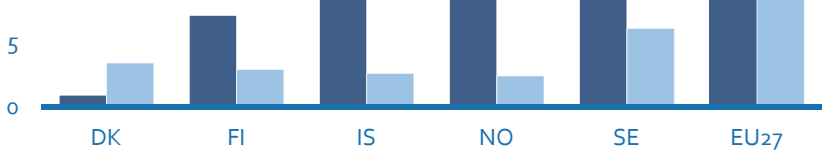

- Ensamstående förälder med hemmavarande barn

- Två eller flera vuxna med hemmavarande barn

皿 Riopo1 


\section{Mottagare av utkomststöd}

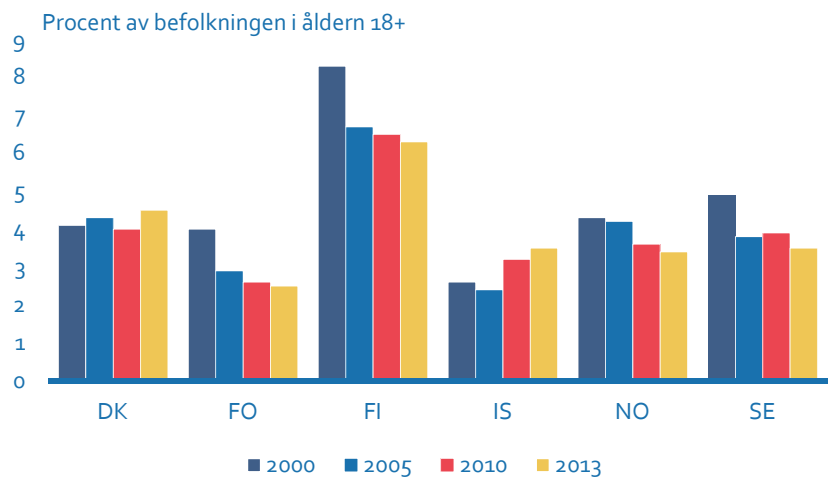

马 Soci12. Färöarna: $2013=2011$ års uppgifter. Finland och Norge: $2013=2012$ års uppgifter.

Sociala utgifter efter finansieringskälla 2013

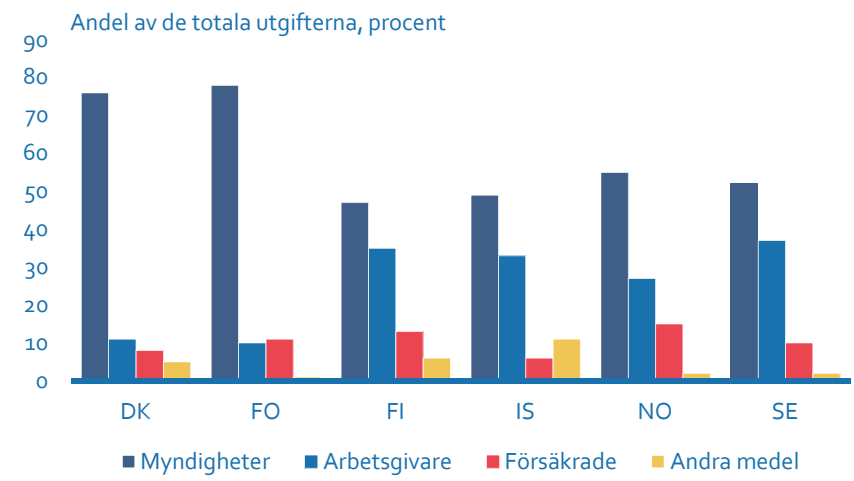

@ Soexo6 
Löneskillnader mellan könen (till fördel för män)

Skillnad i procent

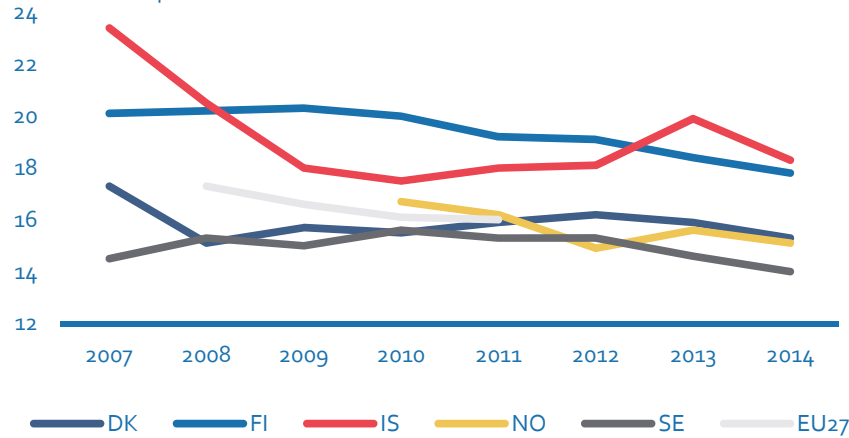

旦 Indic109

Ledamöter invalda till de nationella parlamenten (senaste val)

80 Procent

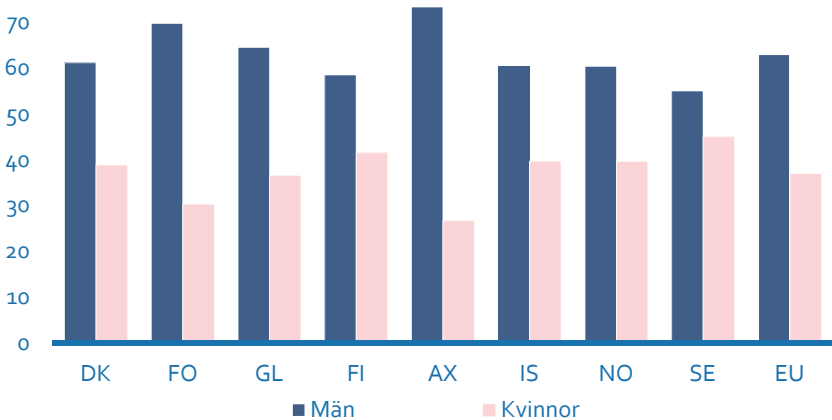

Eleo3 
Giltiga röster vid de två senaste nationella valen

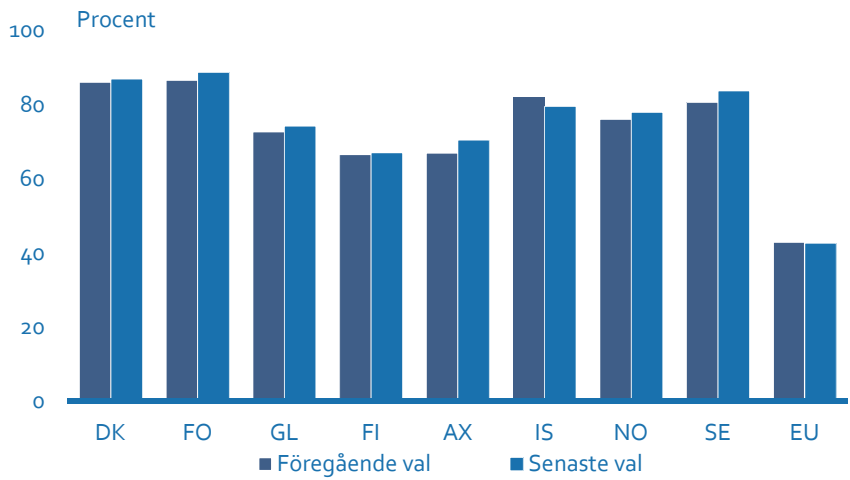

ㅌeo1 


\section{Förtroende och öppenhet}




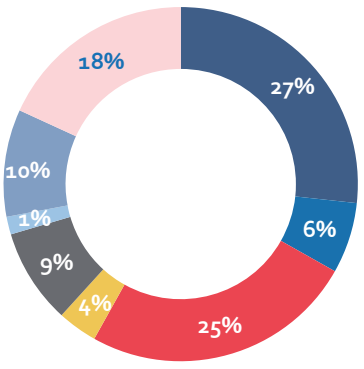

- Inom Norden

- Polen och Baltikum

-Övriga EES

- Övriga Europa

- Amerika

Afrika

Asien

Övriga

Migro2. Finland: 2014 års uppgifter.

Invandring till Norden 2015

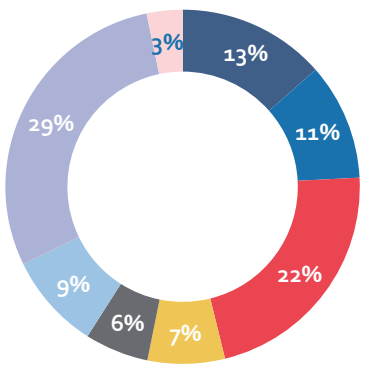

- Inom Norden

- Polen och Baltikum

— Övriga EES

— Övriga Europa

- Amerika

Afrika

Asien

Övriga 
Asylansökningar i Norden 2015

Andel av ansökningarna

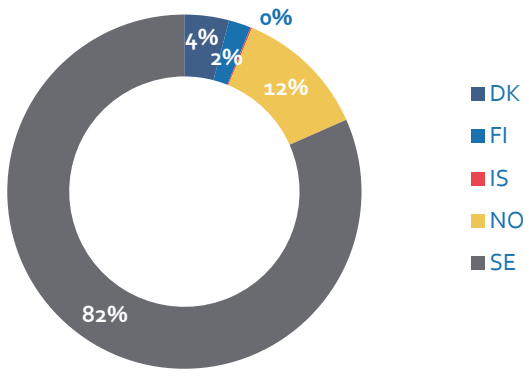

Asylansökningar och beviljade asyl i Norden

250000

200000

150000

100000

50000

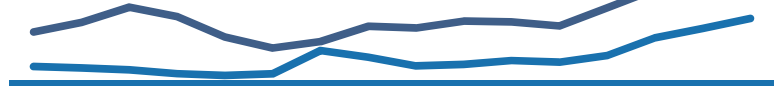

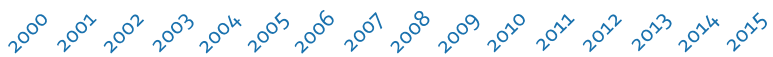

Ansökningar

Beviljade asyl

Digro4 
Ensamkommande barn som söker asyl

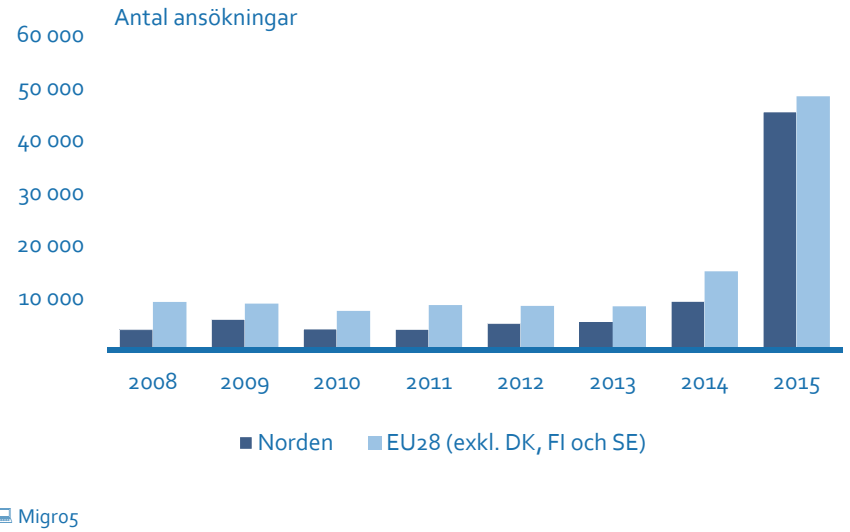




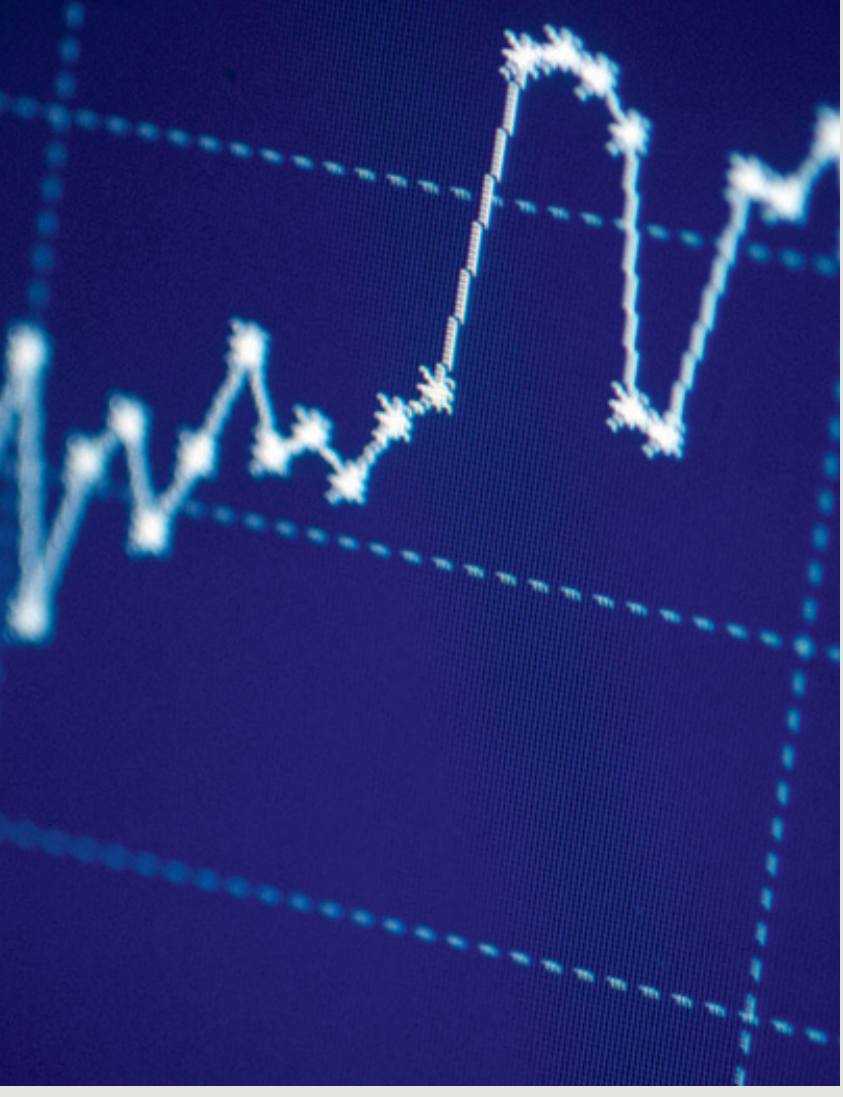

En femtedel av utrikeshandeln i Norden är handel med de andra nordiska länderna. 


\section{Ekonomi}




\section{NYCKELTAL 2015*}

\section{Ekonomi}

\section{Arbetslöshetstal} (procent)

DANMARK

6,3

FINLAND

9,6

ISLAND

4,2

NORGE

$$
4,5
$$

SVERIGE

$$
7,6
$$

ㅌ Key01. *2015 eller senast tillgängliga uppgifter. EA19: De 19 europeiska länder som har infört euron som gemensam valuta per 1 januari 2015. 

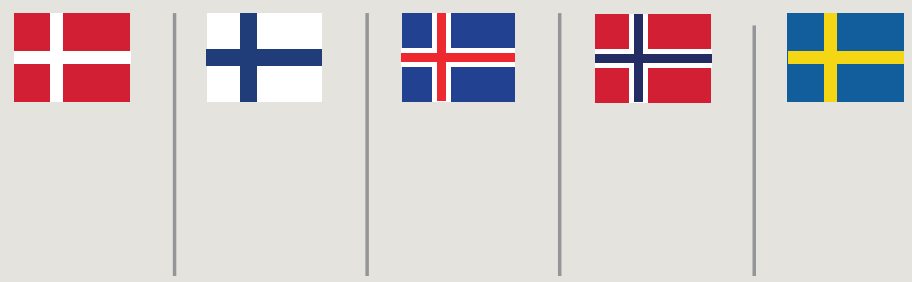

Ekonomisk tillväxt

(procent)

1,2

0,2

4,0

1,6

4,1

Bytesbalans överskott

(procent av BNP)

Ränta

7,0

(procent)
0,7

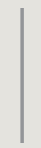

4,2

8,7

5,8

0,7

$1,6 \mid$

6,3

Offentliga sektorns överskott (procent av BNP)
$-2,1$
$-2,7$
$-0,5$
5,7
0,0

Tillväxt i konsumentpriser

(2014-2015, procent)
0,2
$-0$
0,3
2,0
0,7 


\section{Bruttonationalprodukt per person}

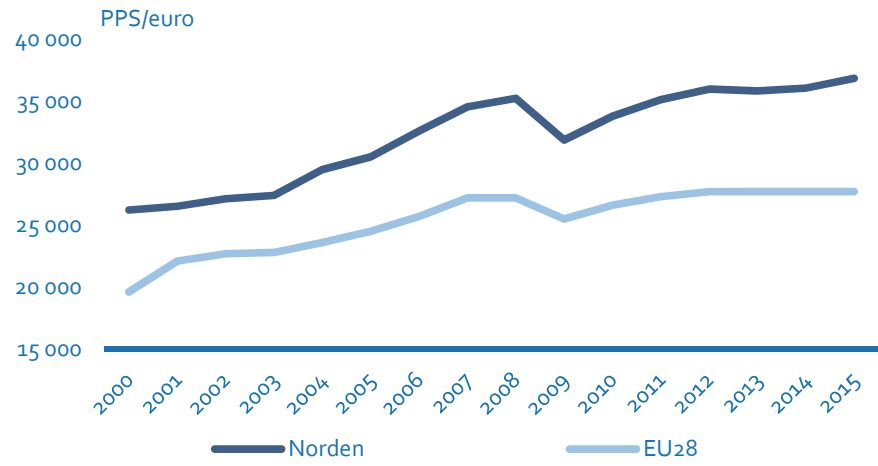

[Indic102. PPS: Purchasing power standards - köpkraftspariteter som eliminerar skillnader i prisnivå mellan länderna.

PPS/euro

49000

44000

39000

34000

29000

24000

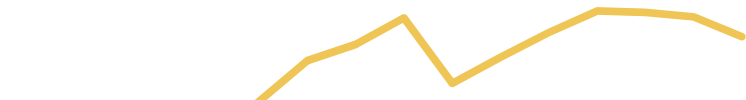

19000

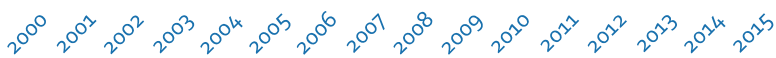

$\longrightarrow \mathrm{DK}$

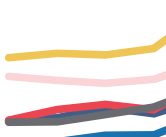




\title{
Bruttonationalprodukt, årlig realtillväxt
}

\author{
6 \\ Procent
}

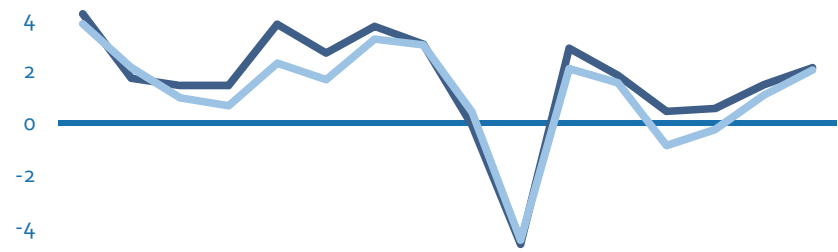

$-6$

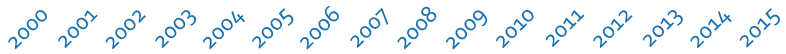

$$
\begin{aligned}
& \text { Norden }
\end{aligned}
$$

Indic401. EA19: De 19 europeiska länder som har infört euron som gemensam valuta per 1 januari 2015 .

\section{Procent \\ 15}

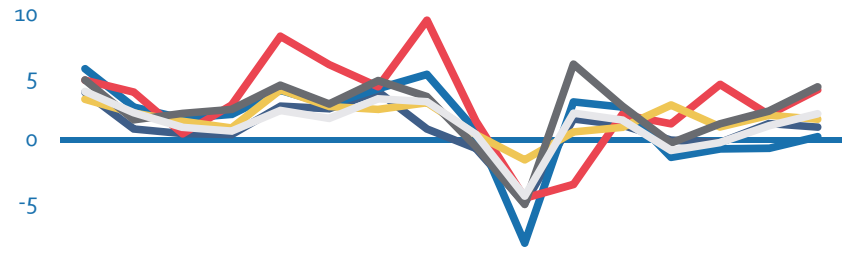

$-10$

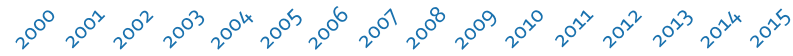

$$
\begin{aligned}
& \longrightarrow \mathrm{DK} \longrightarrow \mathrm{FI} \longrightarrow \mathrm{NO} \rightleftharpoons \mathrm{SE}=\mathrm{EA19}
\end{aligned}
$$

믈 Inc401. EA19: De 19 europeiska länder som har infört euron som gemensam valuta per 1 januari 2015 . 
Handelsbalans för varor - export minus import

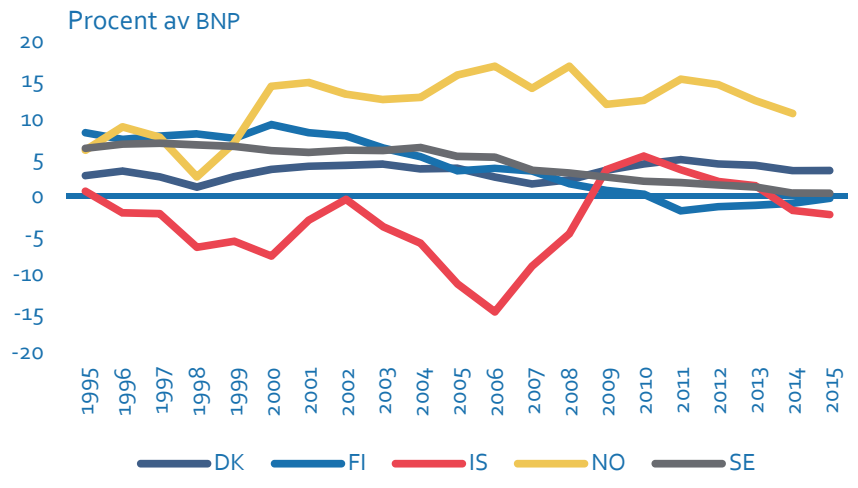

ㅁotr49 och Naaco1

Handel med varor mellan de nordiska länderna

Procent av den totala exporten

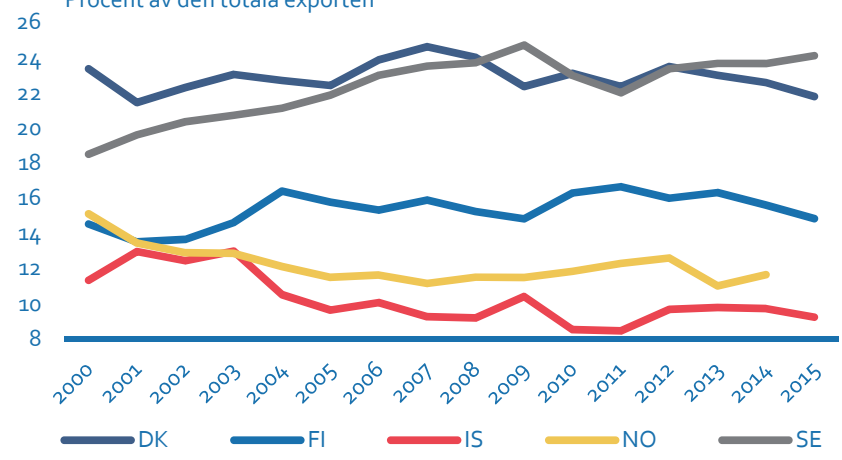

Đotr44 
Handel med varor mellan de nordiska länderna

Procent av den totala importen

32

30

28

26

24

22

20

18

16

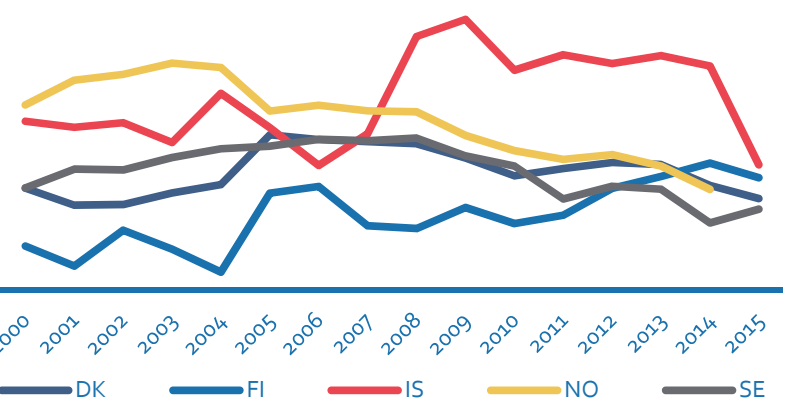

Eotr43 


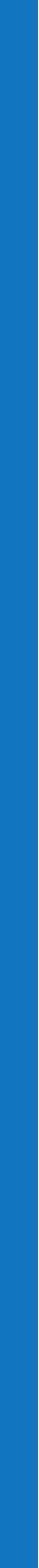




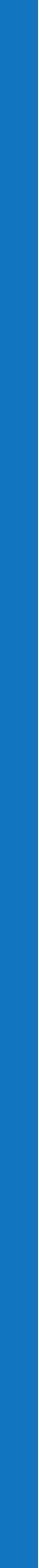


Nordiska ministerrådet

Ved Stranden 18

DK-1061 Köpenhamn K

www.norden.org

\section{Nordisk statistik 2016}

Den här fickversionen innehåller bara ett litet urval ur Nordisk statistik. På www.norden.org/fakta hittar du fler siffror och mer statistik från Norden och de nordiska länderna.

ANP 2016:759

ISBN 978-92-893-4688-7 (PRINT)

ISBN 978-92-893-4689-4 (PDF)

ISSN 2414-6560 (ONLINE)

ISSN 2414-6552 (PRINT) 